Article

\title{
Assessing the Carboxymethylcellulose Copper-Montmorillonite Nanocomposite for Controlling the Infection of Erwinia carotovora in Potato (Solanum tuberosum L.)
}

\author{
Ryan Rienzie ${ }^{1,2}$, Lasantha Sendanayake ${ }^{3}$ D , Devika De Costa ${ }^{1,4}$, Akbar Hossain ${ }^{5, *(D)}$, Marian Brestic ${ }^{6,7}$ (D), \\ Milan Skalicky ${ }^{7, *(D)}$, Pavla Vachova ${ }^{7}$ (D) and Nadeesh M. Adassooriya ${ }^{3,8, *}$
}

check for

updates

Citation: Rienzie, R.; Sendanayake, L.; De Costa, D.; Hossain, A.; Brestic, M.; Skalicky, M.; Vachova, P.; Adassooriya, N.M. Assessing the Carboxymethylcellulose

Copper-Montmorillonite Nanocomposite for Controlling the Infection of Erwinia carotovora in Potato (Solanum tuberosum L.). Nanomaterials 2021, 11, 802. https:// doi.org/10.3390/nano11030802

Academic Editor: Antonios Kelarakis

Received: 24 February 2021

Accepted: 18 March 2021

Published: 21 March 2021

Publisher's Note: MDPI stays neutral with regard to jurisdictional claims in published maps and institutional affiliations.

Copyright: (C) 2021 by the authors. Licensee MDPI, Basel, Switzerland. This article is an open access article distributed under the terms and conditions of the Creative Commons Attribution (CC BY) license (https:/ / creativecommons.org/licenses/by/ $4.0 /)$.
1 Postgraduate Institute of Agriculture, University of Peradeniya, Peradeniya 20400, Sri Lanka; ryanrienzie@gmail.com (R.R.); devikadecosta@gmail.com (D.D.C.)

2 Agribusiness Centre, Faculty of Agriculture, University of Peradeniya, Peradeniya 20400, Sri Lanka

3 Postgraduate Institute of Science, University of Peradeniya, Peradeniya 20400, Sri Lanka; lasanthasendanayake@gmail.com

4 Department of Agricultural Biology, Faculty of Agriculture, University of Peradeniya, Peradeniya 20400, Sri Lanka

5 Department of Agronomy, Bangladesh Wheat and Maize Research Institute, Dinajpur 5200, Bangladesh

6 Department of Plant Physiology, Slovak University of Agriculture, Nitra, Tr. A. Hlinku 2, 94901 Nitra, Slovakia; marian.brestic@uniag.sk

7 Department of Botany and Plant Physiology, Faculty of Agrobiology, Food, and Natural Resources, Czech University of Life Sciences Prague, Kamycka 129, 16500 Prague, Czech Republic; vachovap@af.czu.cz

8 Department of Chemical \& Process Engineering, University of Peradeniya, Peradeniya 20400, Sri Lanka

* Correspondence: akbarhossainwrc@gmail.com (A.H.); skalicky@af.czu.cz (M.S.); nadeeshm@eng.pdn.ac.lk (N.M.A.)

Abstract: A novel antimicrobial formulation based on carboxymethylcellulose (CMC) spray-coated $\mathrm{Cu}^{2+}$ intercalated montmorillonite (MMT) nanocomposite material was prepared and its morphology, internal structure, and bonding interactions were studied. Meanwhile, the antibacterial efficacy and release behavior of $\mathrm{Cu}^{2+}$ was also determined. PXRD patterns indicated the intercalation of $\mathrm{Cu}^{2+}$, while FTIR spectra and TGA traces confirmed the association of $\mathrm{Cu}-\mathrm{MMT}$ with CMC. SEM study revealed the improvement of nanocomposites by $\mathrm{CMC}$, without disturbing the clay structure. TEM and EDAX studies indicated the distribution of $\mathrm{Cu}$ (copper) throughout the composite. In vitro antibacterial assays performed with Erwinia carotovora revealed effective bacterial growth suppression, indicating the potential of this material in controlling soft rot of potatoes (Solanum tuberosum); also observed was a connection between growth inhibition and concentration of CMC spray coats indicating a positive relationship between $\mathrm{Cu}^{2+}$ release and concentration of the $\mathrm{CMC}$ coatings. The activity pattern of the nanocomposite displayed a significant degree of sustained-release behavior.

Keywords: antimicrobial; carboxymethylcellulose; $\mathrm{Cu}^{2+}$ ions; Pectobacterium carotovorum; nanoclay; nanocomposite; bacterial soft rot of potato

\section{Introduction}

Nanoscience-based products and applications have fetched a greater attention in a range of fields including the biocide industry. $\mathrm{Cu}$ is a major active ingredient of chemicals with cidal effects because it is effective against numerous plant and mammalian diseases [1,2]. The use of $\mathrm{Cu}$ in agricultural applications goes back to the 19th century. Inorganic $\mathrm{Cu}$ compounds with fungicidal and bactericidal properties, and as fertilizer additives are very popular due to their low cost [3]. Another advantage possessed by copper is that bacteria and fungi cannot build up resistance against it as they do with antibiotics and synthetic fungicides that are organic in origin. Among the $\mathrm{Cu}$ based biocides, $\mathrm{Cu}\left(\mathrm{NO}_{3}\right)_{2}$, $\mathrm{CuSO}_{4} .5 \mathrm{H}_{2} \mathrm{O}, \mathrm{Cu}(\mathrm{OCl})_{2}, \mathrm{Cu}(\mathrm{OH})_{2}$, and $\mathrm{Cu}_{2} \mathrm{O}$ are more common, with the metallic copper 
content of commercial formulations being generally in the range of 5-85\% [4]. In bacterial cells, $\mathrm{Cu}^{2+}$ causes membrane damage and loss of cell integrity.

Bacterial diseases have gained greater attention in crop agriculture. Soft rot caused by Erwinia sp. is one of the serious diseases that affect many agriculturally important crops [5-7]. Erwinia carotovora subsp. atroseptica van Hall [8] and Dye [9-11] and Erwinia carotovora subsp. carotovora Jones [12]; Bergey et al. [13] are considered as important plant pathogenic species of the genus Erwinia [5], and these subspecies are considered as the main source of primary inoculum for soft rot of potato (S. tuberosum) [5]. Lack of effective control strategies to protect potatoes in the field or during storage has hindered all efforts at inoculation, and therefore the use of non-contaminated planting material has been identified as one of the better control strategies [14].

Recent research showed that by planting cut potato tuber pieces of $60 \mathrm{~g}$ each (optimum size), it is possible to generate better harvests with very high marketable yields in Sri Lanka [15]. However, cutting the tubers results in exposing a considerable surface area of wounded tissues that attract plant pathogenic fungi and bacteria. Therefore, in general, it is advised to store the cut tubers for a couple of days to allow them to develop the corky layer that prevents infection by pathogens; this is followed by dipping the pieces in a suitable fungicide before planting in the soil. Whereas there is a remedy for fungi by treating the planting material with fungicides, there is no particular method to control bacteria such as Erwinia.

The uncontrolled release into the environment after the application is a major problem associated with the use of most pesticides. This results in the accumulation of toxic residues and/or heavy metals in the soil and water bodies [16]. In general, $60-70 \%$ of the pesticides do not reach the target objects and are removed through leaching, volatilization, immobilization, and erosion [17]. Some of these pollutants are heavy metal-based chemicals that tend to accumulate in the environment, with $\mathrm{Cu}$ being one such important heavy metal [18-20]. The presence of excess $\mathrm{Cu}$ has detrimental effects on many organisms as has been emphasized by many researchers [21-25]. However, copper is considered less toxic to humans compared to other heavy metals like cadmium, lead, and mercury [26]. All the same, improving release properties through the formulation of any pesticide plays a major role in combatting such negative impacts. Among such attempts, incorporation of clay and/or polymer matrices together with the active ingredients is one of the widely researched methods.

Clay minerals possess good adsorption properties, cation exchange capacity (CEC) and also facilitate controlled delivery [27]. Antibacterial activity of metal exchanged montmorillonite composites such as $\mathrm{Cu}-$ MMT [26-33], Ag-MMT [29,34], and Zn-MMT [29] have been studied by various researchers. MMT-metal ion composites associated with polymers or resins have also been synthesized and tested [35]. Additionally, other $\mathrm{Cu}$ forms such as $\mathrm{CuO}[36,37]$ and $\mathrm{Cu}_{2} \mathrm{O}[38]$, intercalated with $\mathrm{MMT}$ have also been studied for the same purposes. However, these studies were based on human and animal pathogenic bacteria like Escherichia spp., and mesophilic bacteria—such as Pseudomonas spp., Streptococcus spp., and Salmonella spp.- -and not on plant pathogenic bacteria.

Through the current study, carboxymethylcellulose (CMC) spray-coated $\mathrm{Cu}^{2+}$ intercalated, MMT nanocomposites were prepared and the prepared nanocomposites were fully characterized in terms of their internal structural properties and morphology using powder X-ray diffraction (PXRD), Fourier transformed infrared spectroscopy (FTIR), thermal analysis using thermo gravimetric analysis (TGA), scanning electron microscopy (SEM), and transmission electron microscopy (TEM). In addition to that, in-vitro antibacterial efficacy against Erwinia carotovora was also determined using two experiments. Finally, the release behavior of one composite was studied in sandy soil. CMC was selected because it is a biodegradable polymer that can trigger the sustained release of active ingredients. Employing biodegradable polymers such as carboxymethylcellulose has drawn significant attention compared to synthetic petroleum-derived polymers because biodegradable polymers are less toxic, biocompatible, and biodegradable. Studies have claimed that polymer 
encapsulated formulations are more effective in terms of extended activity than nonencapsulated forms as encapsulation reduces the losses caused by unwanted release [39] whilst the clay component in the composite improves the structural properties of the nanocomposite [40].

\section{Materials and Methods}

\subsection{Preparation of $\mathrm{Cu}^{2+}$ Exchanged $\mathrm{MMT}(\mathrm{Cu}-\mathrm{MMT})$}

A portion of $9 \mathrm{~g}$ of $\mathrm{Na}-\mathrm{MMT}$ (Sigma Aldrich, St. Louis, MO, USA) were weighed and mixed with $200 \mathrm{~mL}$ of $0.05 \mathrm{M} \mathrm{CuSO}_{4} .5 \mathrm{H}_{2} \mathrm{O}$ (Sigma-Aldrich) solution at room temperature $\left(25^{\circ} \mathrm{C}\right)$ and after stirring the mixture was kept overnight. The resulting solution was centrifuged for $20 \mathrm{~min}$ at $5000 \mathrm{rpm}$. Then it was decanted, and the remaining solid material was washed three times with distilled water. Following this, the material was oven-dried for $6 \mathrm{~h}$ at $80{ }^{\circ} \mathrm{C}$. After drying it, a sample of the $\mathrm{Cu}-\mathrm{MMT}$ was analyzed for the percentage of copper by weight using a Thermo Scientific ICE 3500 atomic absorption spectrophotometer (AAS).

\subsection{Preparation of CMC Spray-Coated Cu-MMT Nanocomposites}

CMC (CDH laboratories, New Delhi, India: Viscosity $1 \%$ at $25^{\circ} \mathrm{C}, 1200-2400 \mathrm{cps}$ ) at different concentrations, specifically $2.5,5$ and $7.5 \mathrm{~g} / \mathrm{L}$ were prepared using distilled water heated up to $80^{\circ} \mathrm{C}$. After adding CMC, the solution was continuously stirred for $2 \mathrm{~h}$ and then cooled down to room temperature. The three solutions at room temperature were poured into a spray gun in turn. Prepared $\mathrm{Cu}-\mathrm{MMT}$ from each composite was spread on Petri dishes (2.5 g each) uniformly. Each Petri dish with $\mathrm{Cu}-\mathrm{MMT}$ was sprayed with different strengths of the CMC solutions while slightly shaking the dishes. After spraying, the composites were kept in a drying oven at $60^{\circ} \mathrm{C}$ for $6 \mathrm{~h}$ to remove moisture.

\subsection{Characterization}

\subsubsection{Structural Properties}

PXRD patterns of all synthesized samples were recorded using a Bruker D8 Focus Xray powder diffractometer using $\mathrm{Cu} \mathrm{K}$ radiation $(=0.154 \mathrm{~nm})$ over a $2 \theta$ range of $3-65^{\circ}$ with a step size of $0.02^{\circ}$ and a step time of $1 \mathrm{~s}$. The nature of chemical bonding of the synthesized samples was determined using a Bruker Vertex 80 FTIR spectrometer, by spanning the range from 600 to $4000 \mathrm{~cm}^{-1}$ using the attenuated total reflectance technique. The thermal behavior of the synthesized samples was studied by performing TGA (TA Instruments SDTQ600). The samples (10-15 mg) were heated from ambient temperature to $100{ }^{\circ} \mathrm{C}$ (ramp $10^{\circ} \mathrm{C} / \mathrm{min}$ ) in a nitrogen environment $\left(100 \mathrm{~cm}^{3} / \mathrm{min}_{2}\right.$ flow rate). The particle size and the morphology of the synthesized samples were studied using a HITACHI SU6600 SEM and Philips CM30 TEM and energy dispersive X-ray analysis (EDAX).

\subsubsection{Antibacterial Properties}

Experiment 1: Bacterial Growth Inhibition Test

In-vitro antibacterial activity was assessed using gram-negative bacterium Erwinia carotovora, which was isolated from potatoes showing soft rot symptoms which were collected from a field in Nuwara-Eliya, Sri Lanka. A single bacterial colony of E. carotovora obtained through sub-culturing was inoculated into $50 \mathrm{~mL}$ of nutrient broth (Sigma-Aldrich) and shake-incubated at $30^{\circ} \mathrm{C}$ for $72 \mathrm{~h}$. Then the bacterial cell concentration of the culture was determined by the dilution plate technique. At the same time, Petri dishes with nutrient agar were prepared and wells were bored in the middle of the solidified agar plates. Each well was incorporated with composites of 20,40 , or $60 \mathrm{mg}$ and the wells were again filled with nutrient agar. The composites were exposed to UV light for a period of $6 \mathrm{~h}$ before adding them into the petri dishes. Then $100 \mu \mathrm{L}$ of the E. carotovora culture was spread on the surface of the material in the Petri dishes and incubated at $29 \pm 1{ }^{\circ} \mathrm{C}$ for $24 \mathrm{~h}$. After the incubation period, the diameter of the inhibition zones corresponding to each weight 
level was measured using a Vernier caliper. The experiment was replicated thrice and the average values of the diameters of the inhibition zones were obtained.

Experiment 2: Potato Tuber Inoculation Test

Certified, disease-free potatoes (variety Granola) were used for inoculation. First, the tubers were thoroughly washed with water and then surface sterilized with $\mathrm{NaOCl} 1 \%$ solution. After that, the outer peels were removed. Following that, they were sliced into pieces measuring approximately $2.5 \times 2 \times 0.5 \mathrm{~cm}^{3}$, which were considered as replicates. Each treatment was comprised of 10 replicates of potato pieces weighing approximately $60 \mathrm{~g}$ each (optimum economic size of cut potato that can be used as planting material, according to Mayakaduwa et al. [15].

The following treatments were done using all three $\mathrm{CMC}$ spray-coated $\mathrm{Cu}-\mathrm{MMT}$ nanocomposites $(2.5,5$, and $7.5 \mathrm{~g} / \mathrm{L} \mathrm{CMC})$. The potato pieces in each replicate were treated with either $20 \mathrm{mg}$, $40 \mathrm{mg}$, or $60 \mathrm{mg}$ of each composite (approximately $2 \mathrm{mg}, 4 \mathrm{mg}$, or $6 \mathrm{mg} /$ replicate). As control one group was treated with only Erwinia. In each of the above treatments, every replicate was inoculated with $10 \mu \mathrm{l}$ of $1.2 \times 10^{5} \mathrm{CFU} / \mathrm{mL}$ Erwinia cell suspension. All inoculations were done under aseptic conditions. After three days of inoculation, observations were made and the areas of infection were measured, from which the percentages of infection were calculated using the formula, [(area infected/ total area of the tissue piece) $\times 100$ ] and the values were averaged.

A factor-factorial analysis was performed to determine the effect of concentration of $\mathrm{CMC}$ spray coating and weight of nanocomposites on the percentage of infection in the above two experiments.

\subsubsection{Soil Release Study}

A soil release study was conducted as in soil medium, an interaction takes place between the tubers treated with composites and soil. Accordingly, One $\mathrm{Cu}-\mathrm{MMT}-\mathrm{CMC}$ composite $(\mathrm{Cu}-\mathrm{MMT}-\mathrm{CMC} 5.0 \mathrm{~g} / \mathrm{L})$ out of three was tested for its release behavior and the release of $\mathrm{Cu}$ was compared with pure $\mathrm{CuSO}_{4} \cdot 5 \mathrm{H}_{2} \mathrm{O}$ and uncoated $\mathrm{Cu}-\mathrm{MMT}$. $\mathrm{Cu}-\mathrm{MMT}-\mathrm{CMC} 5.0 \mathrm{~g} / \mathrm{L}$ was selected as it was stable in the presence of atmospheric water. The test was conducted using two potato growing soil types (i.e., sandy soil with low organic matter content and loamy soil with high organic matter content) packed in two leaching columns for seven days. The leachates were analyzed for the quantification of $\mathrm{Cu}$ by means of atomic absorption spectrophotometry (AAS) using a Thermo Scientific ICE 3500 spectrophotometer. The data were plotted as the cumulative percent release of $\mathrm{Cu}$ over time (days). A schematic representation of all experimental procedures is provided in Figure 1. 


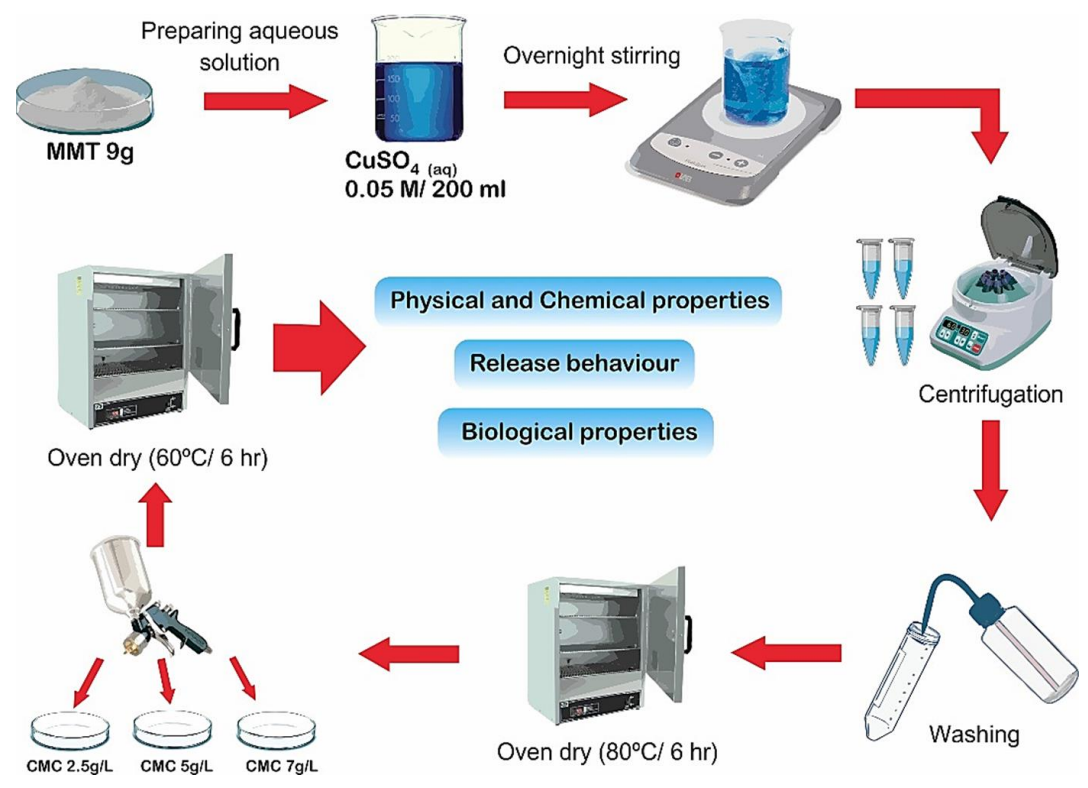

Figure 1. Schematic representation of the experimental procedures.

\section{Results and Discussion}

3.1. Structural Properties

\subsubsection{PXRD Characterization}

The PXRD results provide information about the purity of materials and the crystalline phases present in the prepared nanocomposite. PXRD patterns for MMT, CMC, and $\mathrm{Cu}-\mathrm{MMT}-\mathrm{CMC}$ nanocomposites are shown in Figure 2. Basal $\mathrm{d}_{\text {spacing }}$ values were determined using X-ray diffraction. Accordingly, Na-MMT showed a diffraction peak at $2 \theta=7.40^{\circ}: 1.19 \mathrm{~nm}$ (corresponding interlayer $\mathrm{d}_{001}$ value according to the Bragg equation). $\mathrm{Na}^{+}$ions present in the interlayer space of MMT exchange with $\mathrm{Cu}^{2+}$ ions, causing the $\mathrm{d}_{001}$ value to shift to $1.23 \mathrm{~nm}$ as hydrated $\mathrm{Cu}^{2+}$ ions cause the interlayer distance to increase [41]. Many researchers have reported $\mathrm{d}_{\text {spacing }}$ changes in $\mathrm{Cu}-\mathrm{MMT}$ composites with values ranging from about 1.21 to $1.27[22,28,31,42-48]$. Small new reflections at $2 \theta=13$ in the diffraction patterns of $\mathrm{Cu}-\mathrm{MMT}$ could be due to amorphous $\mathrm{Cu}(\mathrm{OH})_{2} . \mathrm{H}_{2} \mathrm{O}$ [44] while $\mathrm{d}_{\text {spacing }}$ of clays vary with the level of hydration. After spray coating $\mathrm{CMC}$ on $\mathrm{Cu}-\mathrm{MMT}$ particles, interlayer space remains unchanged as it is a surface coating on the solid Cu-MMT particles. It is important to mention that the spray coating of CMC was preferred over the direct addition of $\mathrm{Cu}-\mathrm{MMT}$ into the solution as the acidity of $\mathrm{Cu}^{2+}$ ions might lead to coagulation of CMC. 


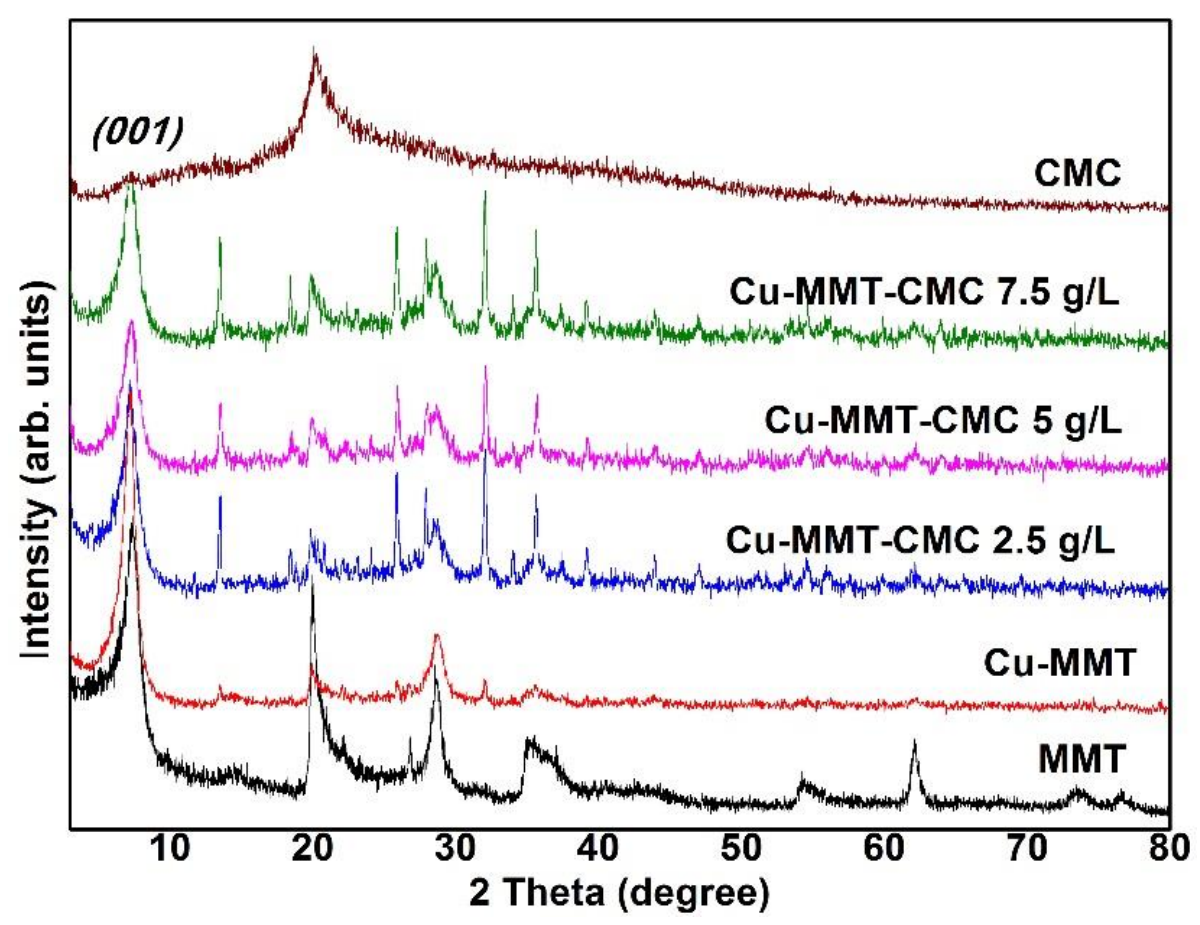

Figure 2. PXRD patterns of $\mathrm{Na}-\mathrm{MMT}, \mathrm{CMC}, \mathrm{Cu}-\mathrm{MMT}$, and $\mathrm{Cu}-\mathrm{MMT}-\mathrm{CMC}$ nanocomposites.

\subsubsection{FTIR Analysis}

FTIR technique is used to study the bonding interactions involve within the nanocomposite as intermolecular bonds play an important role in the release kinetics of active ingredients present in the prepared nanocomposite. FTIR spectra for MMT, CMC, and $\mathrm{Cu}-\mathrm{MMT}-\mathrm{CMC}$ are shown in Figure 3. CMC shows a band at $2908 \mathrm{~cm}^{-1}$ due to C-H stretching of the $-\mathrm{CH}_{2}$ groups and the band due to ring stretching of $-\mathrm{COO}^{-}$appears at $1600 \mathrm{~cm}^{-1}$. In addition, the bands in the region $1350-1450 \mathrm{~cm}^{-1}$ are due to symmetrical deformations of $-\mathrm{CH}_{2}$ and $-\mathrm{COH}$ groups. The bands due to $-\mathrm{CH}_{2} \mathrm{OH}$ stretching mode and $-\mathrm{CH}_{2}$ vibrations appear at 1070 and $1020 \mathrm{~cm}^{-1}$, respectively [49]. MMT shows a characteristic absorption band at $3400 \mathrm{~cm}^{-1}$ due to the $\mathrm{O}-\mathrm{H}$ stretching of adsorbed water and the shoulder at $3628 \mathrm{~cm}^{-1}$ due to structural $-\mathrm{OH}$ groups of MMT. Peaks are seen at $995 \mathrm{~cm}^{-1}$ and $1125 \mathrm{~cm}^{-1}$ are due to Si-O stretching vibrations of MMT layers [47]. In the FTIR spectrum of $\mathrm{Cu}-\mathrm{MMT}-\mathrm{CMC}, \mathrm{O}-\mathrm{H}$ stretching of adsorbed water of MMT shows two lobes at 3350 and $3170 \mathrm{~cm}^{-1}$. In addition, the shoulder at $3628 \mathrm{~cm}^{-1}$ due to structural OH of MMT has shifted slightly to $3622 \mathrm{~cm}^{-1}$. 


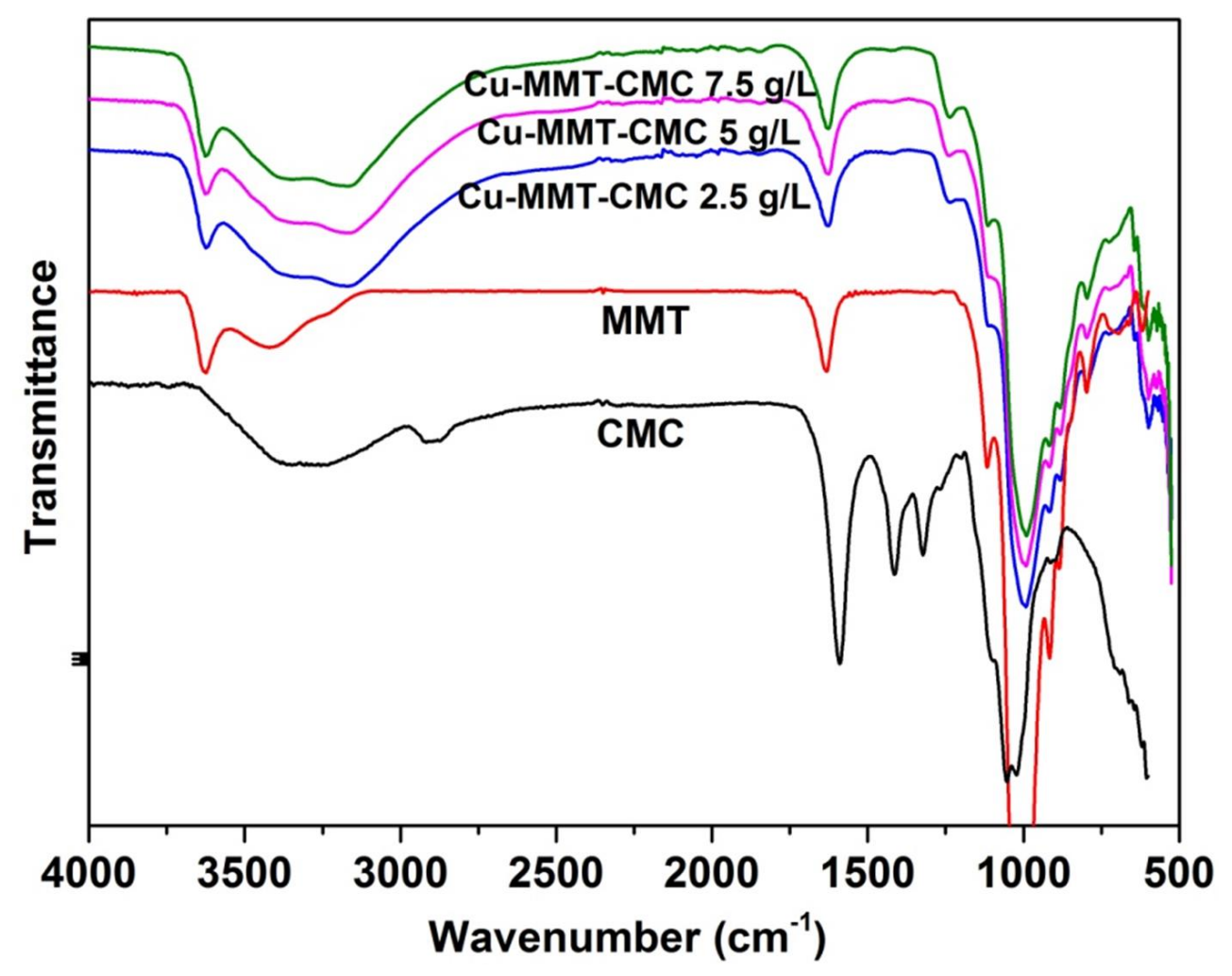

Figure 3. FTIR spectra for $\mathrm{Cu}-\mathrm{MMT}-\mathrm{CMC}$ nanocomposites.

\subsubsection{Thermal Analysis}

The thermal analysis provides the thermal stability of the materials prepared. Here the weight change of the material is determined by heating the sample at a constant rate. TGA and differential thermal analysis (DTA) traces for $\mathrm{Cu}-\mathrm{MMT}-\mathrm{CMC}$ nanocomposites are shown in Figure 4. All three $\mathrm{Cu}-\mathrm{MMT}-\mathrm{CMC}$ nanocomposites show similar thermal events. Up to $200{ }^{\circ} \mathrm{C}$, a total weight loss of approximately $15 \%$ occurs due to dehydration of surface absorbed water in CMC and MMT in the nanocomposite. Furthermore, at around $250{ }^{\circ} \mathrm{C}$, a $2 \%$ weight loss occurs due to the removal of water of the crystallization of $\mathrm{CuSO}_{4}$. The thermal event around $300{ }^{\circ} \mathrm{C}$ is due to the degradation of $\mathrm{CMC}$ [47] in the composites and the losses are in keeping with the concentration of CMC sprayed onto the composites. For instance, the 2.5, 5, and $7.5 \mathrm{~g} \mathrm{~L}^{-1}$ concentration levels show $2 \%, 3 \%$, and $4 \%$ of weight loss, respectively. The thermal peak at $500{ }^{\circ} \mathrm{C}$ is due to further degradation of CMC residues. Those losses are approximately 3\%, 5\%, and $6 \%$ and correspond to the concentrations of $2.5,5$, and $7.5 \mathrm{~g} / \mathrm{L}$, respectively. The prominent thermal event at around $600-700{ }^{\circ} \mathrm{C}$ is due to the collapse of the layered structure of MMT [47]. At $800{ }^{\circ} \mathrm{C}$ another thermal event could be observed due to the removal of $\mathrm{SO}_{2}$ and $\mathrm{O}_{2}$ from $\mathrm{CuSO}_{4}$ leaving behind $\mathrm{CuO}$. Finally, at $1050{ }^{\circ} \mathrm{C}$ another thermal event occurs due to the removal of $\mathrm{O}_{2}$ from $\mathrm{CuO}$ leaving a residue of $\mathrm{Cu}_{2} \mathrm{O}$ (Figures $\mathrm{S} 1$ and $\mathrm{S} 2$ ). 


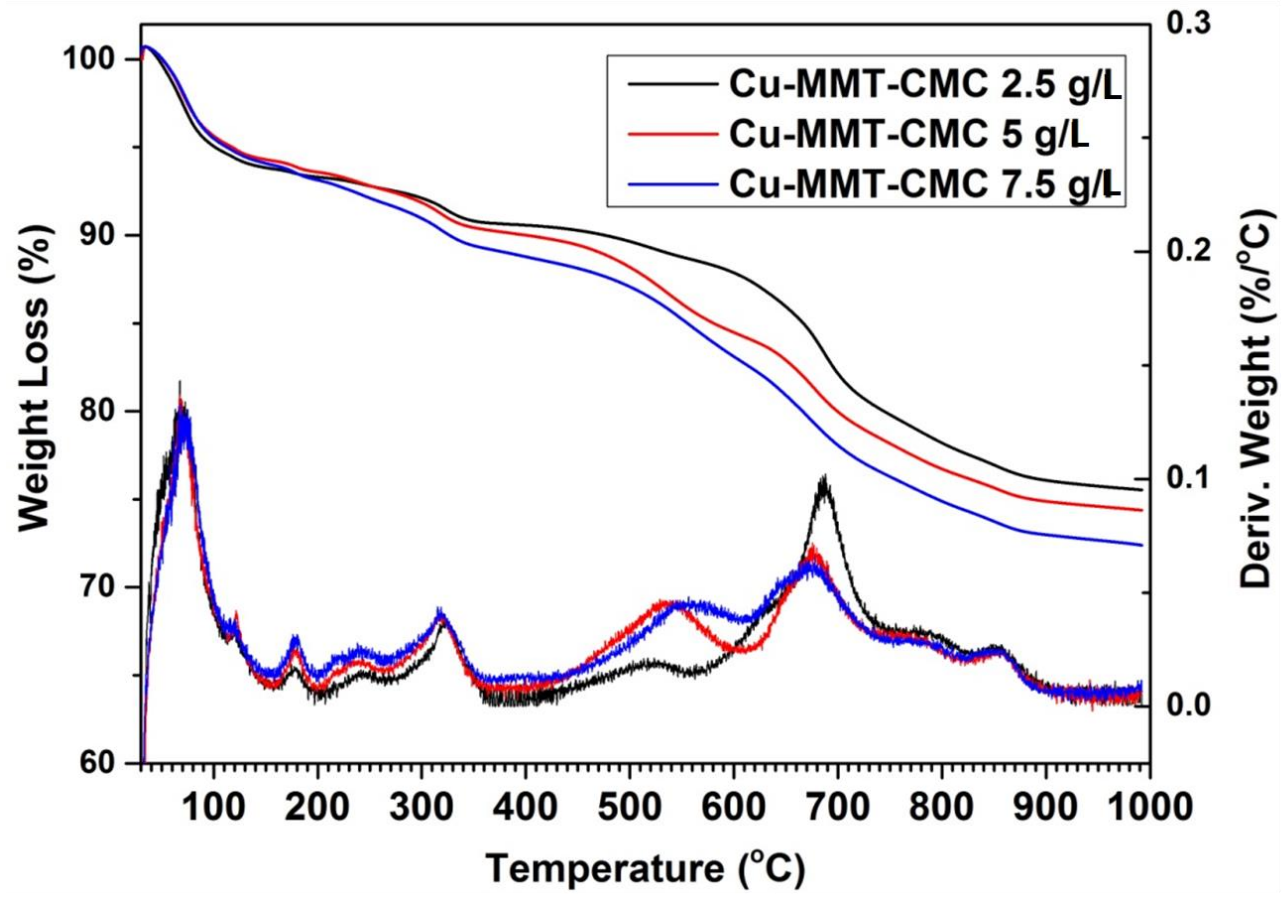

Figure 4. TGA (which denotes weight loss) and DTA (which denotes derivative weight) profiles for $\mathrm{Cu}-\mathrm{MMT}-\mathrm{CMC}$ nanocomposites.

\subsubsection{Microscopy}

Scanning Electron Microscopy (SEM)

SEM technique is used to obtain information on the surface topography of prepared nanocomposites. As seen in Figure 5a,b SEM images show that the plate-like layered structure of MMT continues to remain even after the formation of the composite which facilitates the controlled release behavior of active ingredients present in the nanocomposite. Furthermore, no accumulations of CMC could be seen, confirming the relative uniformity of the spray coats.
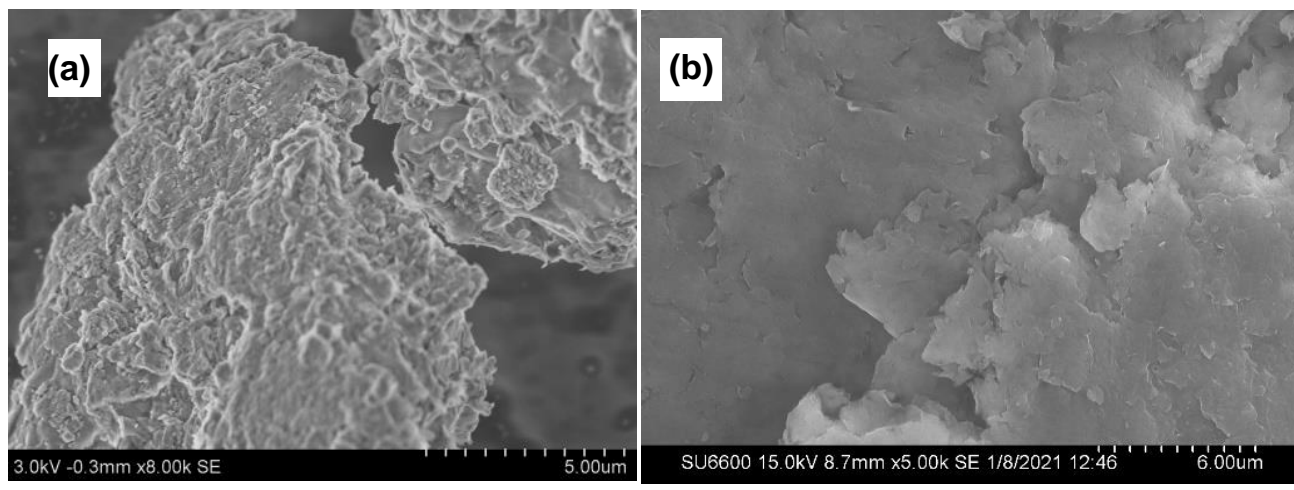

Figure 5. SEM images of $\mathrm{Cu}-\mathrm{MMT}-\mathrm{CMC}$ nanocomposites $(\mathbf{a}, \mathbf{b})$.

Transmission Electron Microscopy (TEM) and Energy Dispersive X-ray Analysis (EDAX)

TEM is vital for the study of the internal features of a material. Also, EDAX provides chemical information about the material. The nanoscale $\mathrm{Cu}-\mathrm{MMT}-\mathrm{CMC}$ nanocomposite can be seen in Figure 6a as having a mixed morphology of a large intercalated tactoid and small intercalated tactoids of MMT clay dispersed throughout the polymer under a magnification of $200 \mathrm{~nm}$. This high magnification shows a large tactoid due to the flocculation of clay layers and a region of small intercalated tactoids together with a few 
intercalated layers. Figure $6 \mathrm{~b}$ shows the $\mathrm{Cu}$ particles intercalated in MMT layers along with the CMC polymer in the form of a network in a dark field TEM image.
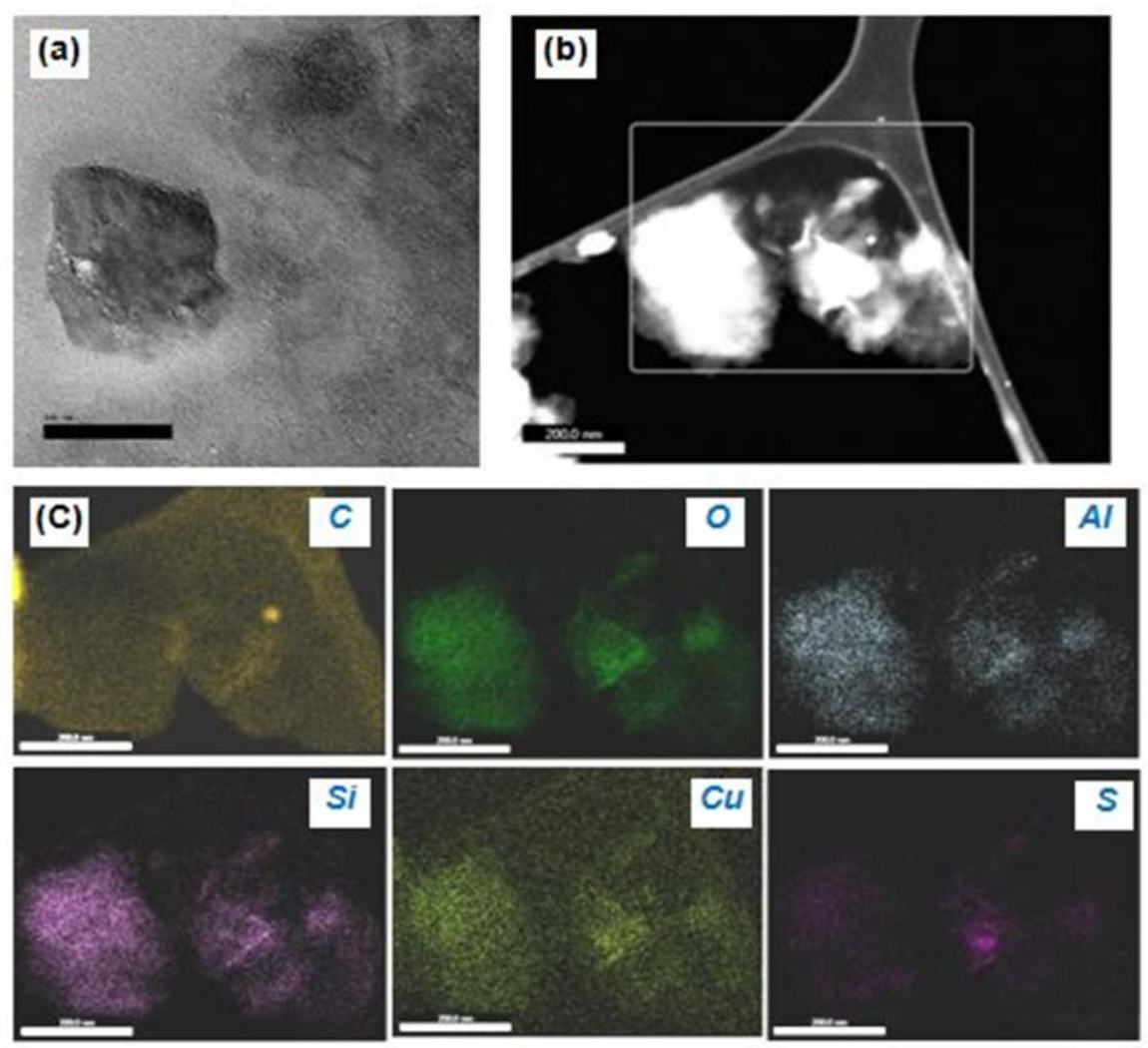

Figure 6. (a) TEM image of $\mathrm{Cu}-\mathrm{MMT}-\mathrm{CMC}$ nanocomposite, (b) area considered for EDAX analysis, and (c) EDAX elemental mapping images showing the existence of MMT layers composed of $\mathrm{C}, \mathrm{O}$, $\mathrm{Al}, \mathrm{Si}, \mathrm{Cu}$, and $\mathrm{S}$ within the $\mathrm{Cu}-\mathrm{CMC}-\mathrm{MMT}$ nanocomposite.

Besides, Figure $6 \mathrm{c}$ shows a nanoscale TEM-EDAX elemental mapping in which MMT layers consisting of $\mathrm{O}, \mathrm{Al}$, and $\mathrm{Si}$ were detected as the primary component of the MMT while CMC polymer consisting of $C$ was detected along with the $C$ which emanates from the sample substrate. $S$ was observed in varying proportions throughout the nanocomposite which arises from sulphate residues present in the nanocomposite. As seen in Figure $6 \mathrm{c}$ TEM-EDAX image of $\mathrm{Cu}$ shows that $\mathrm{Cu}$ is distributed more evenly over the MMT layer compared to other elements.

\subsection{In Vitro Antibacterial Activity Against Plant Pathogenic Erwinia carotovora \\ 3.2.1. Experiment 1: Bacterial Growth Inhibition Test}

The cell concentration of the bacterial culture was determined as $3 \times 10^{9} \mathrm{CFU} / \mathrm{mL}$ through the dilution plate technique. Figure 7 shows the results of a bacterial inhibition test for all three $\mathrm{Cu}-\mathrm{MMT}-\mathrm{CMC}$ nanocomposites whereas Table 1 shows the diameters of the inhibition zones observed. The results clearly indicate that the diameter of the inhibition zone increased with the number of composites tested, indicating the antibacterial activity of all types of nanocomposites used in the study against E. carotovora. 


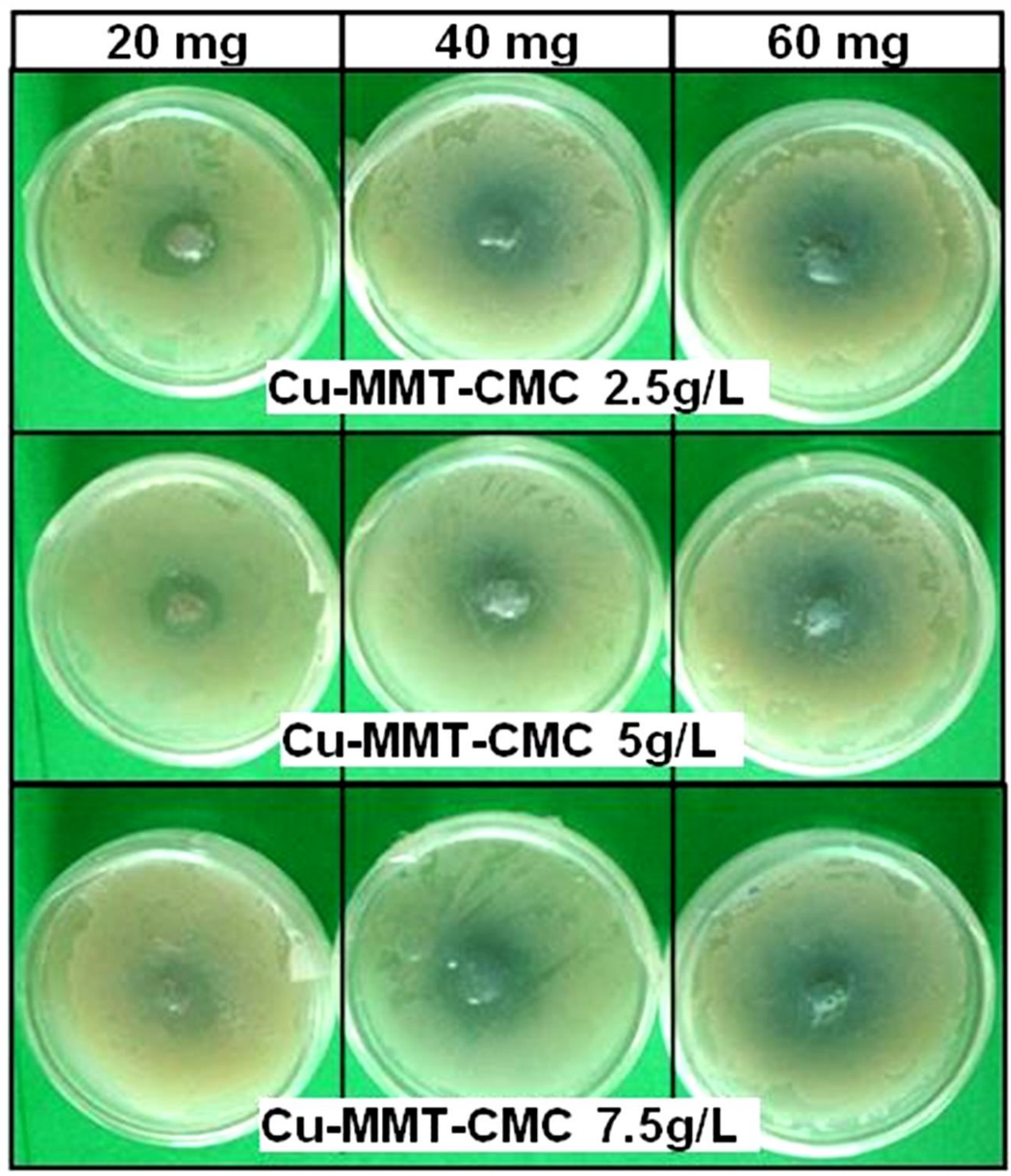

Figure 7. Antibacterial activity of $\mathrm{Cu}-\mathrm{MMT}-\mathrm{CMC}$ nanocomposites.

Table 1. Diameters of the inhibition zones corresponding to various amounts of composites

\begin{tabular}{cccc}
\hline Weight Per Well & $\mathbf{2 0 ~} \mathbf{~ m g}$ & $\mathbf{4 0} \mathbf{~ m g}$ & $\mathbf{6 0} \mathbf{~} \mathbf{g}$ \\
\hline Composite $^{*}$ & \multicolumn{4}{c}{ Diameters of the inhibition zones $(\mathbf{c m})$} \\
\hline C1 & $1.75( \pm 0.0115)$ & $2.40( \pm 0.0)$ & $2.50( \pm 0.153)$ \\
C2 & $1.75( \pm 0.116)$ & $2.36( \pm 0.116)$ & $2.42( \pm 0.300)$ \\
C3 & $1.71( \pm 0.010)$ & $2.15( \pm 0.0115)$ & $2.20( \pm 0.015)$ \\
\hline
\end{tabular}

Prior to the antibacterial test, the average $\mathrm{Cu}$ content of the composites in triplicate was determined through AAS and found to be $9.2 \%, 8.6 \%$ and $8.2 \%$ of $\mathrm{Cu}$ by weight respectively, which corresponded to spray coats of $2.5,5.0$ and $7.5 \mathrm{~g} / \mathrm{L}(\mathrm{C} 1=\mathrm{Cu}-\mathrm{MMT}-\mathrm{CMC} 2.5 \mathrm{~g} / \mathrm{L}, \mathrm{C} 2=\mathrm{Cu}-\mathrm{MMT}-\mathrm{CMC} 5.0 \mathrm{~g} / \mathrm{L}, \mathrm{C} 3=\mathrm{Cu}-\mathrm{MMT}-\mathrm{CMC}, 7.5 \mathrm{~g} / \mathrm{L})$ Values given in parentheses in the table include standard errors of means.

The output of factor-factorial analysis can be interpreted in terms of a particular weight level if a slight reduction of the diameter of the inhibition zone can be observed when the concentration of the CMC spray coat increases. An interaction effect between factors was not significant when the $p$-value was $0.102(p>0.05)$. However, the main effects, the specifical concentration of spray coat and weight were highly significant correspondingly with $p=0.006$ and $p=0.000$ values $(p<0.05)$ to the diameter of the inhibition zone. 
This indicates $\mathrm{Cu}^{2+}$ ions can be released into the medium by penetrating through the polymer network of the medium. Therefore, it can be inferred that the mobility of $\mathrm{Cu}^{2+}$ is more or less in step with the current range of concentration. Compared to the polymercoated nanocomposites, the negative controls, i.e., CMC, MMT $\left(\mathrm{Na}^{+}\right)$, or $\mathrm{MMT}-\mathrm{CMC}$ did not show any antibacterial activity (data not shown) against E. carotovora.

\subsubsection{Experiment 2: Potato Tuber Inoculation Test}

The percent infection was decreased with the increased concentration of the CMC spray coats and increased weight of nanocomposites applied to potato tuber pieces while the control pieces showed higher infection percentages compared to other treatments (Table 2; Figure S3). Here the $\mathrm{Cu}-\mathrm{MMT}-\mathrm{CMC} 2.5 \mathrm{~g} / \mathrm{L}(60 \mathrm{mg})$ showed the lowest percentage of infection. Through the factor-factorial analysis, it was revealed that the concentration of the spray coat has a significant effect on percentage infection with the $p$-value of $0.0016(p<0.05)$. Similarly, the weight of the nanocomposite also showed a significant effect on the percentage of infection $(p<0.001)$. Moreover, the interaction effect of concentration of the spray coat and weight of the nanocomposite was also significant as $p$-value was $0.0057(p<0.05)$.

Table 2. Variation of mean percentages of infection by E. carotovora on potato tuber pieces under different treatments

\begin{tabular}{cccc}
\hline \multirow{2}{*}{ Treatments } & \multicolumn{3}{c}{ Composite Weight Levels } \\
\cline { 2 - 4 } & $\mathbf{2 0} \mathbf{~ m g}$ & $\mathbf{4 0} \mathbf{~ m g}$ & $\mathbf{6 0} \mathbf{~} \mathbf{g}$ \\
\hline Composite & & Mean percentage infection \\
C1 & $0.73( \pm 0.168)$ & $1.68( \pm 0.191)$ & $0.18( \pm 0.267)$ \\
C2 & $2.24( \pm 0.223)$ & $2.12( \pm 0.852)$ & $0.46( \pm 0.329)$ \\
C3 & $2.46( \pm 0.223)$ & $2.26( \pm 0.174)$ & $0.56( \pm 0.527)$ \\
Control & $2.51( \pm 0.142)$ & $2.51( \pm 0.142)$ & $2.51( \pm 0.142)$ \\
\hline
\end{tabular}

$\mathrm{C} 1$ = Cu-MMT - CMC 2.5 g/L, C2 = Cu-MMT-CMC 5.0 g/L, C3 = Cu-MMT-CMC, 7.5 g/L; Control: Untreated potato + E. carotovora; Values given in parentheses in the table include standard errors of means.

$\mathrm{Cu}$ based compounds have been proven to be efficacious against many plant pathogenic bacteria including Erwinia spp. [50]. Cu compounds are widely used against many Erwinia spp. including E. amylovora in apple and pear, E. mangiferae in mango and E. trachiphila in cucurbits [51]. Among the $\mathrm{Cu}$ based compounds, $\mathrm{CuSO}_{4} \cdot 5 \mathrm{H}_{2} \mathrm{O}$ is in common usage for controlling plant pathogenic bacteria [23]. In-vitro experimental results have proven its ability to control plant pathogenic bacteria species belonging to the genus Pectobacterium (formerly in the genus Erwinia) [52].

Interestingly, with respect to the potato crop, Abo-Elyousr et al. [5] have demonstrated that spraying $\mathrm{CuSO}_{4}$ had the highest controlling effect on soft rot caused by E. carotovora. In addition to that, Zhang et al. [53] reported that potato soft rot caused by E. carotovora can be effectively controlled by using $\mathrm{CuSO}_{4}$. Furthermore, Gracia-Garza et al. [54] demonstrated that treatment of greenhouse-grown calla lilies (Zantedeschia sp.) with sub-irrigation laced with $\mathrm{Cu}$ and $\mathrm{Cu}(\mathrm{OH})_{2}$ reduced the soft rot incidence of E. carotovora without compromising the plant growth.

Several other types of bacteria besides the one tested in the present study were studied. For instance, $\mathrm{Cu}-\mathrm{MMT}$ composites were prepared and tested with E. coli and it was found they suppressed the growth of this organism [27,28,31-33]; this showed that the efficaciousness and ability of Cu-MMT were superior to Na-MMT [55]. Ag-MMT was also tested against mesophilic bacteria and bacteria present in lactic acid by Costa et al. [34] and against E. faecium by Magaña et al. [30], which showed it to be efficacious in all these cases. MMT exchanged with $\mathrm{Cu}, \mathrm{Ag}$, and $\mathrm{Zn}$, when tested against E. coli, Pseudomonas ostreatus and $P$. cinnabarinus had shown promising results in respect of suppression of growth of those bacteria [29]; in the same study, it was reported that $\mathrm{Cu}-\mathrm{MMT}$ is efficacious over $\mathrm{Cu}^{2+}$. Furthermore, certain studies had reported that $\mathrm{Cu}^{2+}$ intercalated MMT can bind with polymers to enhance the sustained release nature of $\mathrm{Cu}^{2+}$ into the medium and act against $E$. 
coli and S. aureus effectively. For example, this led to the development of a $\mathrm{Cu}-\mathrm{MMT}$-epoxy resin [35]. Furthermore, epoxy matrices with $\mathrm{CuO}$ nanoparticles embedded in MMT [37] and $\mathrm{Cu}_{2} \mathrm{O}$ embedded in octadecyl amine-modified MMT [21] have also been studied and found to be very effective at suppressing the growth of E. coli. Therefore, the present study provides new insights into employing $\mathrm{Cu}$-MMT-polymer composites for controlling plant diseases.

In general, positively charged biomaterial-i.e., polymer surfaces show an antimicrobial effect on adhering Gram-negative bacteria [56]. Replacement of $\mathrm{Na}^{+}$in $\mathrm{Na}-\mathrm{MMT}$ by $\mathrm{Cu}^{2+}$ increases the presence of positive charges on the surface and in the interlayer space of MMT where the Gram-negative bacteria tend to get attached. E. carotovora is a Gram-negative bacterium that is highly vulnerable to $\mathrm{Cu}^{2+}[29,31]$. The addition of a biopolymer like $\mathrm{CMC}$ on $\mathrm{Cu}-\mathrm{MMT}$ particles further enhances the release of $\mathrm{Cu}^{2+}$ ions by absorbing moisture from the environment. Moisture absorption by CMC due to its highly hydrophilic carboxylic group causes the CMC composite to swell to a marked extent, depending mainly upon the $\mathrm{pH}$ of the medium $[57,58]$. The MMT also increases the swelling capacity of certain composites, i.e., CMC-g-poly (acrylamide)-MMT [59].

In Sri Lanka, losses caused by E. carotovora are significant in certain economically important crops [60,61]. As observed, farmers in Sri Lanka tend to cut the seed potato instead of the whole tuber to minimize the costs incurred. Under such situations, infestations could be higher as the cut surfaces facilitate the penetration process. Furthermore, $\mathrm{Cu}^{2+}$ is not only efficacious against bacteria, but it also affects soil-borne fungi such as Phytopthora spp. Its broad range of action against organisms that destroy crops has favored higher usage of $\mathrm{Cu}^{2+}$ throughout the world.

\subsection{Soil Release Study}

The cumulative amounts of $\mathrm{Cu}$ released plotted against time from $\mathrm{CuSO}_{4} \cdot 5 \mathrm{H}_{2} \mathrm{O}$, $\mathrm{Cu}-\mathrm{MMT}$, and $\mathrm{Cu}-\mathrm{MMT}-\mathrm{CMC}$ were measured using a sandy soil sample. The results are shown in Figure 8. Overall, the $\mathrm{Cu}$ releasing pattern from pure $\mathrm{Cu}$ (from $\mathrm{CuSO}_{4}$ ) and $\mathrm{Cu}-\mathrm{MMT}$ nanocomposite are similar when compared to $\mathrm{Cu}-\mathrm{MMT}-\mathrm{CMC}$ nanocomposite, which nearly leveled off after the third day.

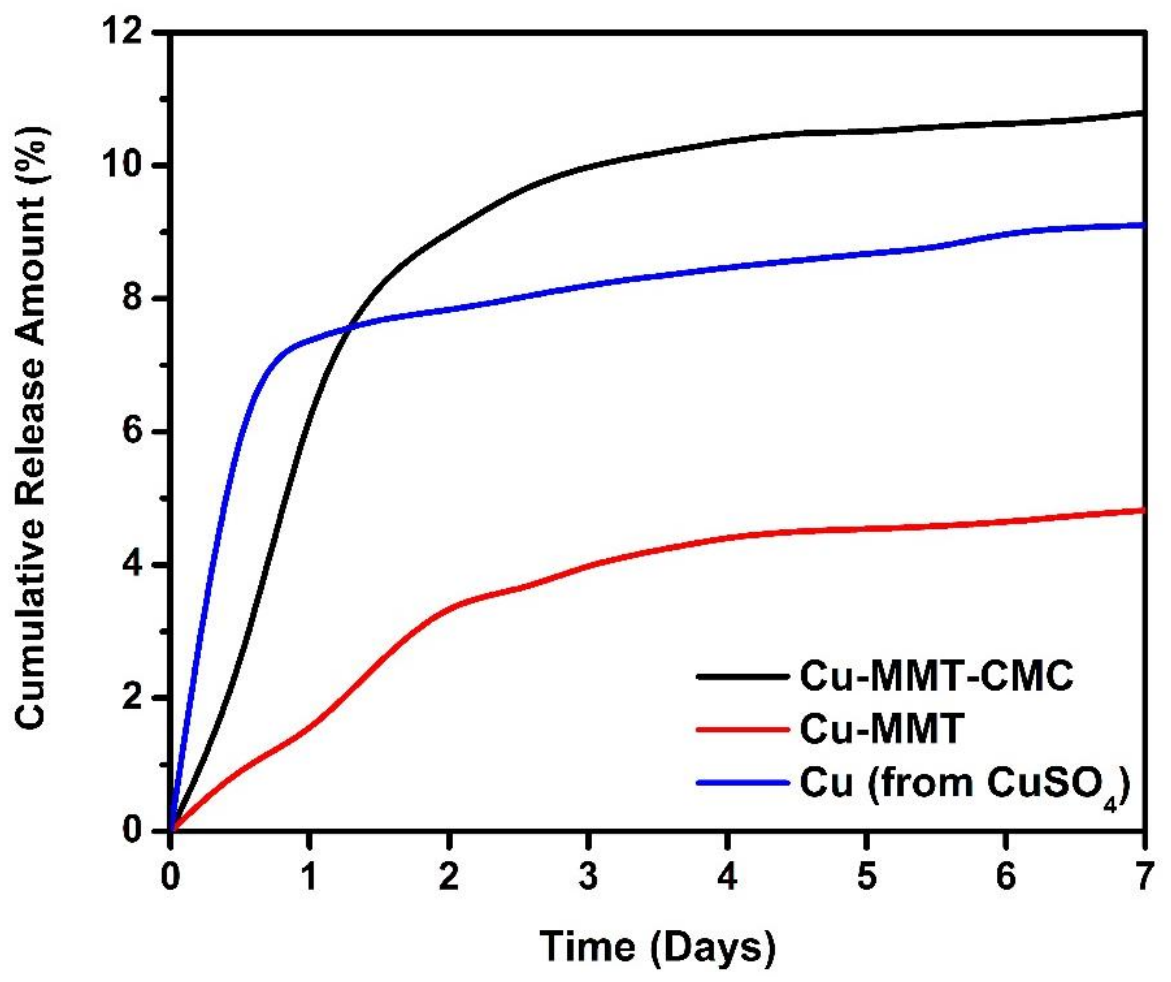

Figure 8. Cumulative release of $\mathrm{Cu}^{2+}$ from $\mathrm{Cu}-\mathrm{MMT}-\mathrm{CMC} 5.0 \mathrm{~g} / \mathrm{L}, \mathrm{Cu}-\mathrm{MMT}$, and $\mathrm{CuSO}_{4} .5 \mathrm{H}_{2} \mathrm{O}$. 
As shown in the results, at the end of the first $12 \mathrm{~h}, \mathrm{Cu}-\mathrm{MMT}-\mathrm{CMC}$ cumulative release percentage was around 2.2. The release percentage gets gradually increased to five times of initial quantity until day 5 and then gets leveled off just over $10.5 \%$. Initially, there is a $1 \%$ of $\mathrm{Cu}$ release from $\mathrm{Cu}-\mathrm{MMT}$ and then slightly increased release behavior up to $4.5 \%$ of $\mathrm{Cu}$ at $120 \mathrm{~h}$ which is similar to the $\mathrm{Cu}-\mathrm{MMT}-\mathrm{CMC}$ nanocomposite. Nearly two times lower release of $\mathrm{Cu}$ from $\mathrm{Cu}-\mathrm{MMT}$ than $\mathrm{Cu}-\mathrm{MMT}-\mathrm{CMC}$ may be due to the non-covalent intercalation of $\mathrm{Cu}$ inside the MMT layers that induces the slow release even though they had similar kinetics. The burst release of $\mathrm{Cu}-\mathrm{MMT}-\mathrm{CMC}$ nanocomposite (coated) compared to $\mathrm{Cu}-\mathrm{MMT}$ can be due to $\mathrm{CMC}$ coating. $\mathrm{CMC}$ absorbs and retains water which swells to facilitate dissolution of more trapped $\mathrm{Cu}$ within MMT and after that release through diffusion to the surrounding.

Based on the results obtained for pure $\mathrm{Cu}$, the instantaneous $\mathrm{Cu}$ release was observed on the first $12 \mathrm{~h}$ which is around 7\%. Despite this, the rest release pattern of pure $\mathrm{Cu}$ showed moderately increasing behavior reaching nearly $9 \%$ around day 7 . However, the comparative analysis indicated that the nanocomposite had a slow-release behavior followed by instantaneous release due to the absence of modifications compared to the other two formulations. Thus, it reveals that the addition of $\mathrm{CMC}$ to the $\mathrm{Cu}-\mathrm{MMT}$ $(\mathrm{Cu}-\mathrm{MMT}-\mathrm{CMC})$ nanocomposite might concentrate much of the copper inside nanocomposite giving the ability to release $\mathrm{Cu}$ in a gradually increasing manner and the same time $\mathrm{Cu}$ ions which have been loaded to the intercalated MMT(Cu-MMT) layers enabling them to be released in a slow and controlled manner. In general, the release pattern of $\mathrm{Cu}$ from $\mathrm{Cu}-\mathrm{MMT}-\mathrm{CMC}$ gives a better and controlled release behavior in comparison to the other two forms.

In contrast, the leachate of potato soil with higher organic matter content did not contain $\mathrm{Cu}$. Thus, releasing around $10 \%$ of $\mathrm{Cu}$ from the composite incorporated into the sandy soil is considerable. The reasons behind on not containing $\mathrm{Cu}$ in the leachate might be the complexation and coagulation of $\mathrm{Cu}$ with humic acids [62], which might be an underlying cause that prevents releasing $\mathrm{Cu}$ in this case.

\section{Conclusions}

Through the current work, $\mathrm{Cu}$ intercalated montmorillonite nanocomposites coated with three different concentration of CMC spray were formulated and characterized for their essential properties. FTIR spectra and TGA traces confirmed the association of $\mathrm{Cu}-\mathrm{MMT}$ with $\mathrm{CMC}$. The plate-like appearance of MMT was maintained even after nanocomposite formation which is vital for controlled release behavior. All three $\mathrm{Cu}-\mathrm{MMT}-\mathrm{CMC}$ nanocomposites showed antibacterial activity against $E$. carotovora making them suitable for tuber treatments. Furthermore, in the agar plate experiment, antimicrobial activity was slightly reduced when the concentration of the CMC spray coats increased; this implied that the $\mathrm{Cu}^{2+}$ ions released into the medium by penetrating through the polymer network were slightly affected by the CMC coating on the $\mathrm{Cu}-\mathrm{MMT}$ particles. When the composite was tested for the release of $\mathrm{Cu}^{2+}$, it was found that it could release $\mathrm{Cu}^{2+}$ instantaneously, followed by a controlled release pattern. Furthermore, it carries a great commercial potential as clays and biodegradable CMC are environmentally friendly, biocompatible, and economically viable.

Supplementary Materials: The following are available online at https:/ / www.mdpi.com/2079-499 1/11/3/802/s1, Figure S1: TGA curve of MMT; Figure S2: TGA curves of CMC; and Figure S3: TGA curves of CMC.

Author Contributions: Conceptualization, R.R., D.D.C., and N.M.A.; Methodology, R.R., D.D.C., L.S., and N.M.A.; Software, R.R.; Validation, R.R., D.D.C., L.S., and N.M.A.; Formal analysis, R.R. and N.M.A.; Investigation, R.R.; Resources, D.D.C. and N.M.A.; Data curation, R.R.; Writing-original draft preparation, R.R., D.D.C., L.S., and N.M.A.; Writing-review and editing, A.H., M.B., M.S., and P.V.; Visualization, R.R.; Supervision, D.D.C. and N.M.A.; Project administration, N.M.A. and M.S.; Funding acquisition, A.H., M.B., M.S., and P.V. All authors have read and agreed to the published version of the manuscript. 
Funding: This study was supported by an S-grant from the Ministry of Education, Youth and Sports of the Czech Republic.

Institutional Review Board Statement: Not applicable.

Informed Consent Statement: Not applicable.

Data Availability Statement: Most of the recorded data are available in Tables and Figures of the manuscripts.

Acknowledgments: Authors thankful to the Department of Agricultural Biology, Faculty of Agriculture, University of Peradeniya (UoP) for providing laboratory facilities. Authors also grateful to the Department of Chemistry, University of Cambridge, the UK for the support given for material characterization. Furthermore, all authors are thankful to the Postgraduate Institute of Agriculture (UoP) and the Agribusiness Centre of the Faculty of Agriculture (UoP), Sri Lanka, for their inputs in statistical analysis.

Conflicts of Interest: The authors declare no conflict of interest.

\section{References}

1. Epstein, L.; Bassein, S. Pesticide Applications of Copper on Perennial Crops in California, 1993 to 1998. J. Environ. Qual. 2001, 30, 1844-1847. [CrossRef]

2. He, Z.L.; Yang, X.E.; Stoffella, P.J. Trace elements in agroecosystems and impacts on the environment. J. Trace Elem. Med. Biol. 2005, 19, 125-140. [CrossRef]

3. Dias, M.C. Phytotoxicity: An Overview of the Physiological Responses of Plants Exposed to Fungicides. J. Bot. 2012, 2012, 1-4. [CrossRef]

4. Behlau, F.; Scandelai, L.H.M.; Junior, G.J.D.S.; Lanza, F.E. Soluble and insoluble copper formulations and metallic copper rate for control of citrus canker on sweet orange trees. Crop. Prot. 2017, 94, 185-191. [CrossRef]

5. Abo-Elyousr, K.A.; Allam, A.D.A.; Sallam, M.A.; Hassan, M.H.A. Role of certain potato tubers constituents in their resistance to bacterial soft rot caused by Erwinia carotovora pv. carotovora. Arch. Phytopathol. Plant Prot. 2010, 43, 1190-1197. [CrossRef]

6. Snehalatharani, A.; Khan, A.N.A. Biochemical and physiological characterisation of Erwinia species causing tip-over disease of banana. Arch. Phytopathol. Plant Prot. 2010, 43, 1072-1080. [CrossRef]

7. Żołobowska, L.; Pospieszny, H. Diversity of soft rot Erwinias occurring on economically important crops in Poland. Arch. Phytopathol. Plant Prot. 1999, 32, 355-364. [CrossRef]

8. Van Hall, C.J.J. Bijdragen Tot de Kennis der Bakterieele Plantenzeikten, Cooperatieve Drukerij-Vereeniging "Plantijn". Inaugural Dissertation, Amsterdam, The Netherlands, 1902.

9. Dye, D.W. A taxonomic study of the genus Erwinia. n. The "carotovora" group. N. Z. J. Sci. 1969, 12, 81-97.

10. Dye, D.W. A taxonomic study o.f the genus Erwinia. III. The "herbicola" group. N. Z. J. Sci. 1969, 12, $223-236$.

11. Dye, D.W. A taxonomic study o.fthe genus Erwinia. IV. “Atypical” Erwinias. N. Z. J. Sci. 1969, 12, 833-839.

12. Jones, L.R. Bacillus carotovorus n. sp. die Ursache einer weichen Faulnis der M6hre. Cent. Bakteriol. Parasitenkd. Infekt. Krankh. 1901, 2, 12-21.

13. Bergey, D.H.; Harrison, F.C.; Breed, R.S.; Hammer, B.W.; Huntoon, F.M. Bergey's Manual of Determinative Bacteriology, 1st ed.; Williams \& Wilkins Co: Baltimore, MA, USA, 1923.

14. Hyman, L.; Dewasmes, V.; Toth, I.; Perombelon, M. Improved PCR detection sensitivity of Erwinia carotovora subsp. atroseptica in potato tuber peel extract by prior enrichment on a selective medium. Lett. Appl. Microbiol. 1997, 25, 143-147. [CrossRef]

15. Mayakaduwa, M.A.P.; Babu, A.G.C.; Nugaliyadde, M.M.; Peter, J.; Kahawandala, K.R.S.C.B.; Nishshanka, N.I.J.H. Performance of seed tuber pieces of potato as planting material under up country wet zone conditions. Ann. Sri Lanka Dep. Agric. 2017, 19, 129-138.

16. Fan, J.; He, Z.; Ma, L.Q.; Stoffella, P.J. Accumulation and availability of copper in citrus grove soils as affected by fungicide application. J. Soils Sediments 2011, 11, 639-648. [CrossRef]

17. Al-Rajab, A.J.; Hakami, O.M. Behavior of the non-selective herbicide glyphosate in agricultural soil. Am. J. Environ. Sci. 2014, 10, 94-101. [CrossRef]

18. Msaky, J.J.; Tanaka, U.; Mizuta, J.; Kosaki, T. Copper levels in soils treated with fungicides under traditional agroforestry (kihamba) system in Moshi District, Tanzania. Jpn. J. Trop. Agric. 2002, 46, 230-238.

19. Mirlean, N.; Roisenberg, A.; Chies, J.O. Metal contamination of vineyard soils in wet subtropics (southern Brazil). Environ. Pollut. 2007, 149, 10-17. [CrossRef] [PubMed]

20. Wightwick, A.M.; Mollah, M.R.; Partington, D.L.; Allinson, G. Copper Fungicide Residues in Australian Vineyard Soils. J. Agric. Food Chem. 2008, 56, 2457-2464. [CrossRef]

21. de Oliveira-Filho, E.C.; Lopes, R.M.; Paumgartten, F.J.R. Comparative study on the susceptibility of freshwater species to copper-based pesticides. Chemosphere 2004, 56, 369-374. [CrossRef] [PubMed]

22. Xia, M.S.; Hu, C.H.; Xu, Z.R.; Ye, Y.; Zhou, Y.H.; Xiong, L. Effects of Copper-bearing Montmorillonite (Cu-MMT) on Escherichia coli and Diarrhea on Weanling Pigs. Asian Australas. J. Anim. Sci. 2004, 17, 1712-1716. [CrossRef] 
23. Van Zwieten, L.; Rust, J.; Kingston, T.; Merrington, G.; Morris, S. Influence of copper fungicide residues on occurrence of earthworms in avocado orchard soils. Sci. Total Environ. 2004, 329, 29-41. [CrossRef]

24. Eijsackers, H.; Beneke, P.; Maboeta, M.; Louw, J.; Reinecke, A. The implications of copper fungicide usage in vineyards for earthworm activity and resulting sustainable soil quality. Ecotoxicol. Environ. Saf. 2005, 62, 99-111. [CrossRef]

25. Georgopoulos, P.G.; Roy, A.; Lioy, M.J.; Opiekun, R.E.; Lioy, P.J. Environmental copper: Its dynamics and human exposure issues. J. Toxicol. Environ. Health Part B 2001, 4, 341-394. [CrossRef]

26. Lepp, N.W. (Ed.) Effect of Heavy Metal Pollution on Plants: Effects of Trace Metals on Plant Function; Springer Netherlands: Dordrecht, Netherlands, 2012; 352 p. [CrossRef]

27. Wanyika, H. Controlled Release of Agrochemicals Intercalated into Montmorillonite Interlayer Space. Sci. World J. 2014, 2014, 1-9. [CrossRef] [PubMed]

28. Bruna, J.E.; Penaloza, A.; Guarda, F.; Rodriguez, F.; Galotto, M.J. Development of MtCu2+/LDPE nanocomposites with antimicrobial activity for potential use in food packaging. Appl. Clay Sci. 2012, 58, 79-87. [CrossRef]

29. Malachova, K.; Praus, P.; Rybkova, Z.; Kozak, O. Antibacterial \& antifungal activities of silver, copper and zinc montmorillo-nites. Appl. Clay Sci. 2011, 53, 642-645.

30. Magaña, S.; Quintana, P.; Aguilar, D.; Toledo, J.; Ángeles-Chávez, C.; Cortés, M.; León, L.; Freile-Pelegrín, Y.; López, T.; Sánchez, R.T. Antibacterial activity of montmorillonites modified with silver. J. Mol. Catal. A Chem. 2008, 281, 192-199. [CrossRef]

31. Hu, C.-H.; Xia, M.-S. Adsorption and antibacterial effect of copper-exchanged montmorillonite on Escherichia coli K88. Appl. Clay Sci. 2006, 31, 180-184. [CrossRef]

32. Tong, G.; Yulong, M.; Peng, G.; Zirong, X. Antibacterial effects of the Cu(II)-exchanged montmorillonite on Escherichia coli K88 and Salmonella choleraesuis. Veter Microbiol. 2005, 105, 113-122. [CrossRef]

33. Zhou, Y.; Xia, M.; Ye, Y.; Hu, C. Antimicrobial ability of Cu-montmorillonite. Appl. Clay Sci. 2004, 27, 215-218. [CrossRef]

34. Costa, C.; Conte, A.; Buonocore, G.; del Nobile, M. Antimicrobial silver-montmorillonite nanoparticles to prolong the shelf life of fresh fruit salad. Int. J. Food Microbiol. 2011, 148, 164-167. [CrossRef]

35. Bartolozzi, A.; Bertani, R.; Burigo, E.; Fabrizi, A.; Panozzo, F.; Quaresimin, M.; Simionato, F.; Sgarbossa, P.; Tamburini, S.; Zappalorto, M.; et al. Multifunctional Cu2+-montmorillonite/epoxy resin nanocomposites with antibacterial activity. J. Appl. Polym. Sci. 2017, 134, 44733. [CrossRef]

36. Nouri, A.; Yaraki, M.T.; Ghorbanpour, M.; Agarwal, S.; Gupta, V.K. Enhanced Antibacterial effect of chitosan film using Montmorillonite/CuO nanocomposite. Int. J. Biol. Macromol. 2018, 109, 1219-1231. [CrossRef] [PubMed]

37. Sohrabnezhad, S.; Moghaddam, M.M.; Salavatiyan, T. Synthesis and characterization of CuO-montmorillonite nanocomposite by thermal decomposition method and antibacterial activity of nanocomposite. Spectrochim. Acta Part A Mol. Biomol. Spectrosc. 2014, 125, 73-78. [CrossRef]

38. De, B.; Gupta, K.; Mandal, M.; Karak, N. Biocide immobilized OMMT-carbon dot reduced $\mathrm{Cu}_{2} \mathrm{O}$ nanohybrid/hyperbranched epoxy nanocomposites: Mechanical, thermal, antimicrobial and optical properties. Mater. Sci. Eng. C 2015, 56, 74-83. [CrossRef] [PubMed]

39. Roy, A.; Singh, S.K.; Bajpai, J.; Bajpai, A.K. Controlled pesticide release from biodegradable polymers. Open Chem. 2014, 12, 453-469. [CrossRef]

40. Lam, C.-K.; Lau, K.-T.; Cheung, H.-Y.; Ling, H.-Y. Effect of ultrasound sonication in nanoclay clusters of nanoclay/epoxy composites. Mater. Lett. 2005, 59, 1369-1372. [CrossRef]

41. Bahranowski, K.; Dula, R.; Labanowska, M.; Serwicka, E.M. ESR study of Cu centers supported on AI-, Ti-, and Zr-pillared montmorillonite clays. Appl. Spectrosc. 1996, 50, 1439-1445. [CrossRef]

42. Bruna, J.; Galotto, M.; Guarda, A.; Rodriguez, F. A novel polymer based on MtCu2+/cellulose acetate with antimicrobial activity. Carbohydr. Polym. 2014, 102, 317-323. [CrossRef]

43. Bruna, J.E.; Quilodrán, H.; Guarda, A.; Rodríguez, F.; Galotto, M.J.; Figueroa, P. Development of antibacterial MtCu/PLA nanocomposites by casting method for potential use in food packaging. J. Chil. Chem. Soc. 2015, 60, 3009-3014. [CrossRef]

44. Martucci, J.F.; Ruseckaite, R.A. Antibacterial activity of gelatin/copper (II)-exchanged montmorillonite films. Food Hydrocoll. 2017, 64, 70-77. [CrossRef]

45. Wu, Y.; Zhou, N.; Li, W.; Gu, H.; Fan, Y.; Yuan, J. Long-term and controlled release of chlorhexidine-copper (II) from organ-ically modified montmorillonite (OMMT) nanocomposites. Mater. Sci. Eng. C Mater. Biol. Appl. 2013, 1, 752-757. [CrossRef] [PubMed]

46. Kozák, O.; Praus, P.; Machovič, V.; Klika, Z. Adsorption of zinc and copper ions on natural and ethylenediamine modified montmorillonite. Ceram. Silikáty 2010, 54, 78-84.

47. Madusanka, N.; de Silva, K.N.; Amaratunga, G. A curcumin activated carboxymethyl cellulose-montmorillonite clay nanocomposite having enhanced curcumin release in aqueous media. Carbohydr. Polym. 2015, 134, 695-699. [CrossRef] [PubMed]

48. Purwar, R.; Verma, A.; Batra, R. Antimicrobial gelatin/sericin/clay films for packaging of hygiene products. J. Polym. Eng. 2019, 39, 744-751. [CrossRef]

49. Ismail, N.M.; Bono, A.; Valentinus, A.C.S.; Nilus, S.; Chang, L.M. Optimization of reaction conditions for preparing carboxymethylcellulose. J. Appl. Sci. 2010, 10, 2530-2536. [CrossRef]

50. Blom, T.J.; Brown, W. Preplant Copper-based Compounds Reduce Erwinia Soft Rot on Calla Lilies. HortTechnology 1999, 9, 56-59. [CrossRef] 
51. Rusjan, D. Copper in Horticulture, Fungicides for Plant and Animal Diseases; Dhanasekaran, D., Thajuddin, N., Panneerselvam, A., Eds.; InTech: Rijeka, Croatia, 2012. [CrossRef]

52. Czajkowski, R.; Pérombelon, M.C.M.; van Veen, J.A.; van der Wolf, J.M. Control of blackleg and tuber soft rot of potato caused by Pectobacterium and Dickeya species: A review. Plant Pathol. 2011, 60, 999-1013. [CrossRef]

53. Zhang, X.J.; Wang, J.S.; Fang, Z.D. Control of potato soft rot (Erwinia carotovora subsp. carotovora (Jones) Dye) by copper sulphate and its effect on some enzymes in tubers. Acta Phytopathol. Sin. 1993, 23, 75-79.

54. Gracia-Garza, J.A.; Allen, W.; Blom, T.J.; Brown, W. Pre-and post-plant applications of copper-based compounds to control Erwinia soft rot of calla lilies. Can. J. Plant Pathol. 2002, 24, 274-280. [CrossRef]

55. Guo, Z.; Li, Y.; Zhang, S.; Niu, H.; Chen, Z.; Xu, J. Enhanced sorption of radiocobalt from water by Bi (III) modified montmorillonite: A novel adsorbent. J. Hazard. Mater. 2011, 192, 168-175.

56. Gottenbos, B.; Grijpma, D.W.; van der Mei, H.C.; Feijen, J.; Busscher, H.J. Antimicrobial effects of positively charged surfaces on adhering Gram-positive and Gram-negative bacteria. J. Antimicrob. Chemother. 2001, 48, 7-13. [CrossRef]

57. Chang, C.; Duan, B.; Cai, J.; Zhang, L. Superabsorbent hydrogels based on cellulose for smart swelling and controllable delivery. Eur. Polym. J. 2010, 46, 92-100. [CrossRef]

58. Sarkar, D.J.; Singh, A. pH-triggered release of boron and thiamethoxam from boric acid crosslinked carboxymethyl cellulose hydrogel based formulations. Polym. Plast. Technol. Mater. 2019, 58, 83-96. [CrossRef]

59. Kenawy, E.-R.; Azaam, M.M.; El-Nshar, E.M. Preparation of carboxymethyl cellulose-g-poly (acrylamide)/montmorillonite superabsorbent composite as a slow-release urea fertilizer. Polym. Adv. Technol. 2018, 29, 2072-2079. [CrossRef]

60. Kayalvily, T.D.; Jegathambigai, V.; Karunarathne, M.D.S.D.; Svinningen, A.; Mikunthan, G. Prevalence of Erwinia soft rot affecting cut foliage, Dracaena sanderiana ornamental industry and solution towards its management. Commun. Agric. Appl. Boil. Sci. 2012, 77, 265-273.

61. Wasana, W.P.; Kuruppuarachchi, K.A.P.P.; Yapa, P.N.; Hettiarachi, S. Antimicrobial activity of selected spices against Pectobacterium carotovorum isolated from some vegetables in Sri Lanka. J. Sci. Univ. Kelaniya Sri Lanka 2019, 12, 34. [CrossRef]

62. Boguta, P.; d' Orazio, V.; Sokołowska, Z.; Senesi, N. Effects of selected chemical and physicochemical properties of humic acids from peat soils on their interaction mechanisms with copper ions at various pHs. J. Geochem. Explor. 2016, 168, 119-126. [CrossRef] 